\title{
Altered distribution of peripheral blood dendritic cell subsets in patients with pulmonary paracoccidioidomycosis
}

\author{
James Venturini ${ }^{\mathrm{a}, \mathrm{b}, *}$, Ricardo Souza Cavalcante ${ }^{\mathrm{a}}$, Daniela Vanessa Moris ${ }^{\mathrm{c}}$, \\ Márjorie de Assis Golim ${ }^{\mathrm{a}}$, Adriele Dandara Levorato ${ }^{\mathrm{a}}$, Karoline Hagatha dos Reis ${ }^{\mathrm{b}}$, \\ Maria Sueli Parreira de Arruda ${ }^{\mathrm{b}}$, Rinaldo Poncio Mendes ${ }^{\mathrm{a}}$ \\ ${ }^{a}$ Faculdade de Medicina de Botucatu, UNESP - Univ Estadual Paulista, Distrito de Rubião Junior s/n, 18618-970, Botucatu, SP, Brazil \\ b Faculdade de Ciências, UNESP - Univ Estadual Paulista, Av. Eng. Luiz Edmundo C. Coube 14-01, 17033-360, Bauru, SP, Brazil \\ ${ }^{c}$ Universidade do Oeste Paulista - UNOESTE, Rua José Bongiovani, 700, 19050-920, Presidente Prudente - SP, Brazil
}

\section{A R T I C L E I N F O}

\section{Keywords:}

Paracoccidioides

Plasmacytoid dendritic cells

Myeloid dendritic cells

Antifungal treatment

Pulmonary fibrosis

Emphysema

\begin{abstract}
A B S T R A C T
Paracoccidioidomycosis (PCM) is a systemic mycosis caused by fungi from the genus Paracoccidioides in Latin America. PCM-patients (PCM-p) are classified as having acute/subacute or chronic (CF) clinical forms. CF is responsible for $75 \%-90 \%$ of all cases, affects mainly adults over 30 years old and the clinical manifestation are associated mainly with lungs and mucosa of upper airdigestive tract. In addition, the CF patients exhibit fibrosis of the lungs, oral mucous membranes and adrenals, and pulmonary emphysema. Consequently, CF PCM-p with active disease, as well as those that have been apparently cured, seem to be an interesting model for studies aiming to understand the long-term host-fungi relationship and hypoxia. Dendritic cells (DCs) constitute a system that serve as a major link between innate and adaptive immunity composed of several subpopulations of cells including two main subsets: myeloid (mDCs) and plasmacytoid (pDCs). The present study aimed to access the distribution of PBDC subsets of CF PCM-p who were not treated (NT) or treated (apparently cured - AC). CF PCM-p were categorized into two groups, consisting of 9 NTs and 9 ACs. Twenty-one healthy individuals were used as the control group. The determination of the PBDC subsets was performed by FACS (fluorescence-activated cell sorting) and the dosage of serum TNF- $\alpha$, IL1 $\beta$, IL-18, CCL3, IL-10 and basic fibroblast growth factor (bFGF) by ELISA (enzyme-linked immunosorbent assay). A high count and percentage of mDCs was observed before treatment, along with a low count of pDCs in treated patients. Furthermore, the mDC:pDC ratio and serum levels of TNF- $\alpha$ was higher in both of the PCM-p groups than in the control group. In conclusion, our findings demonstrated that active PCM influences the distribution of mDCs and pDCs, and after treatment, PCM-p retained a lower count of pDCs associated with pro-inflammatory profile. Therefore, we identified new evidences of persistent immunological abnormalities in PCM-p after treatment. Even these patients showing fungal clearance after successful antifungal treatment; the hypoxia, triggered by the persistent pulmonary sequelae, possibly continues to interfere in the immune response.
\end{abstract}

\section{Introduction}

Paracoccidioidomycosis (PCM) is the main endemic systemic mycosis in Latin America, where it is confined, and it is caused by thermodimorphic fungi from the genus Paracoccidioides (Shikanai-Yasuda et al., 2006; Teixeira et al., 2009). PCM-patients (PCM-p) exhibit an impaired antigen-specific cellular immune response, and the disease presents as two main distinct clinical forms, acute/subacute (AF) and chronic (CF) (Benard et al., 1996; Mendes, 1994).

$\mathrm{AF}$ affects young individuals and has clinical manifestations that involve the lymph nodes, liver, spleen and bone marrow. CF is the most prevalent clinical form, usually affects male adults older than 30 years, and shows a predominant pulmonary and mucocutaneous involvement. In this clinical form, the disease is usually caused by reactivation of latent foci that remained in the host for an unknown amount of time, which may be as long as 30 years (Mendes, 1994); thus, the host has already organized an adaptive immune response against the genus Paracoccidioides that was efficacious for some time. In addition, sequelae such as pulmonary fibrosis (PF) and emphysema (EMPH) are a hallmark in CF; despite they have been commonly identified during the

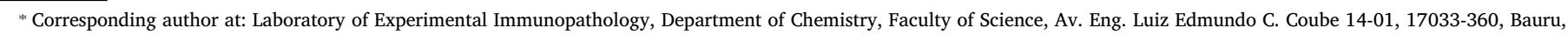
São Paulo, Brazil.

E-mail address: james@fc.unesp.br (J. Venturini). 
diagnosis, there is no treatment and these conditions trigger serious economic, social and psychological problems (Mendes, 1994). Itraconazole is the first choice for PCM treatment; although this azole is efficacious and safe, the duration of the therapy is prolonged, sometimes reaching more than two years (Cavalcante et al., 2014).

Dendritic cells (DCs) are involved in linking innate immunity to adaptive immunity, are responsible for the antigen presentation to $\mathrm{T}$ lymphocytes, trigger the polarization of the adaptive immune response and induce immune tolerance and/or anergy (Kapsenberg, 2003). Several reports have shown the importance of these cells in experimental PCM models (Almeida and Lopes, 2001; Ferreira and Almeida, 2006; Ferreira et al., 2011, 2007; Magalhães et al., 2012; Pina et al., 2013; Silvana dos Santos et al., 2011; Tavares et al., 2012), but few studies have been performed in patients. Some researchers have demonstrated an altered distribution of DCs in the skin and/or mucocutaneous lesions from PCM-p (Gimenez et al., 1987; Kaminagakura et al., 2007; Pagliari and Sotto, 2003), and others have found that monocytederived DCs of treated PCM-p show a higher expression of HLA-DR, DCSIGN, CD86 and higher production of IL-12p40 than patients with active disease and healthy individuals (Sato et al., 2011). Recently, Fernandes et al. (2015) showed that $P$. brasiliensis yeast cells impair the maturation of monocyte-derived DCs of normal individuals. Although these reports using monocyte-derived cells have shown important aspects of immunobiology of DCs in PCM, there is a lack of studies evaluating freshly isolated DCs from PCM-p.

Because of different phenotypic and functional properties, peripheral blood DCs are subdivided into the following two main populations: myeloid (mDCs) and plasmacytoid (pDCs) DCs (Ziegler-Heitbrock et al., 2010). mDCs originate from myeloid precursors, express a high amount of $\beta 2$ integrin $(\mathrm{CD} 11 \mathrm{c})$ and secrete IL-12, inducing a T helper type 1 (Th1) immune response that is crucial in immunity against intracellular pathogens (MacDonald et al., 2002; Osugi et al., 2002). pDCs produce large amounts of type I interferon (IFN-I), inducing Th2 response; they have been associated with viral immunity and the induction of immunological tolerance (Colonna et al., 2004). In the mucosal tissues, mDCs (conventional DCs) are predominantly found in the underlying tissue and express CD1c or CD141 on surface and the transcription factor IRF4 in the lung; pDCs exist expressing CD103 and are associated with the pulmonary epithelium (review in (Cook and MacDonald, 2016))

A recent report showed that B10.A mice, a mouse strain susceptible to $P$. brasiliensis, have a higher percentage of pulmonary mDCs and a lower percentage of pDCs than A/J mice, the resistant strain (Pina et al., 2013). Moreover, while the $P$. brasiliensis-induced mDCs of susceptible mice triggered high production of pro-inflammatory cytokines associated with intense initial tissue damage and the development of a specifically impaired adaptive immune response, the $P$. brasiliensis-induced pDCs of resistant mice produced large amounts of TGF- $\beta 1$ associated with initial permissive fungal growth but followed by an efficient cellular-mediated immune response and subsequent fungal clearance (Pina et al., 2013).

Considering that: 1) the distribution and role of subsets in PCM patients remain to be evaluated; 2) CF PCM patients with active disease and those who were apparently cured seems to be an interesting model for studies aiming to understand the long-term host-fungus relationship as well as hypoxia; the present study aimed to access the distribution of peripheral blood DC (PBDC) subsets in CF PCM-p with active disease, either before treatment or after being apparently cured.

\section{Methods}

\subsection{Patients}

Eighteen CF PCM patients (PCM-p) from the Tropical Diseases Ward and Outpatient Clinic for Paracoccidioidomycosis at the University Hospital, Faculdade de Medicina de Botucatu (FMB), UNESP-Univ.
Estadual Paulista, Botucatu, SP, Brazil, were studied. Cases with clinical manifestations that were compatible with PCM were considered either confirmed or probable [13]. Cases were considered confirmed when the typical Paracoccidioides genus yeast forms were identified in the clinical specimens and considered probable when only serum-specific antibodies were detected using a double agar gel immunodiffusion test (DID). All patients had pulmonary involvement and were classified as having clinical CF. Radiologic evaluation of chest injuries by CTScan was performed in 12 patients (Supp Table S1 in the online version at DOI: http://dx.doi.org/10.1016/j.actatropica.2017.06.007). Patients who exhibited neoplasia, inflammation, other infectious diseases or pregnancy were not enrolled.

\subsection{Ethics statement}

This study was approved by the Research Ethics Committee of FMBUNESP (\#3145/2009). After being informed of the study, written informed consent was obtained from all participating adults.

\subsection{Experimental design}

PCM-p were categorized into the following two groups: the nontreated (NT) group, consisting of 9 newly diagnosed patients, and the apparent cure (AC) group, consisting of 9 PCM-p who did not show any signs or symptoms and had a normal erythrocyte sedimentation rate (ESR), negative serology, and at least 2 full years of non-treatment after complete antifungal therapy, which are all characteristics of an apparent cure [6]. The groups were homogeneous as to gender, age, degree of severity, specific antibody serum levels at admission and antifungal treatment (Table 1). Twenty-one age- and gender-matched healthy individuals were selected among blood donors from the same geographical area to constitute the control group (CG) (Table 1).

\subsection{Determination of the peripheral blood ( $P B)$ dendritic cell (DC) subsets}

Venous blood was collected in Vacutainer tubes (BD, Becton Dickinson, Franklin Lakes, NJ, USA) containing EDTA anticoagulant. Whole blood $(100 \mu \mathrm{l})$ was added to polystyrene tubes containing the following monoclonal antibodies: AlexaFluor ${ }^{\circ} 488$-conjugated lineage cocktail (mouse anti-human CD3, CD14, CD19, CD20, CD56); phycoerythrin (PE)-conjugated mouse anti-human CD123; peridinin chlorophyll protein complex (PerCP)-conjugated mouse anti-human HLA-DR; and allophycocyanin (APC)-conjugated mouse anti-human CD11c, all of which were purchased from BioLegend (San Diego, CA, USA). The tubes were incubated with the conjugated antibodies for $20 \mathrm{~min}$ at $4{ }^{\circ} \mathrm{C}$. Next, the erythrocytes were lysed by resuspension in FACS lysing solution. The cells were washed with BD Pharmingen ${ }^{\text {TM }}$ staining buffer and analyzed using a FACSCalibur (BD). Absolute counts number of DCs subsets was based on WBC. The data were analyzed using the FlowJo software (Tree Star Inc., USA). The normal range of the percentage of total DCs and the $\mathrm{mDC} / \mathrm{pDC}$ ratio used in this study was based on a study performed by Riccardi et al. (2011).

\subsection{Dosage of serum mediators}

Serum levels of TNF- $\alpha$, IL-1 $\beta$, IL-18, CCL3 and bFGF were quantified the DuoSet ${ }^{@}$ ELISA Development kit (R \& D systems, Minneapolis, MI, USA) according to the manufacturer's instructions.

\subsection{Statistical analysis}

The statistical tests were performed using the GraphPad v.5.00 software (GraphPad Software Inc., San Diego, CA, USA), and the significance was defined at $p \leq 0.05$ for all of the analyses. The homogeneity of the NT, AC, and control groups was determined by MannWhitney $U$ test, Fisher's exact test, and Kruskal-Wallis test. The 
Table 1

Clinical characterization of 18 paracoccidioidomycosis patients and healthy individuals.

\begin{tabular}{|c|c|c|c|c|}
\hline Parameters & $\begin{array}{l}\text { Non-treated group } \\
\text { (NT) } \\
{[n=9]}\end{array}$ & $\begin{array}{l}\text { Apparent cure group } \\
\text { (AC) } \\
{[n=9]}\end{array}$ & $\begin{array}{l}\text { Control group } \\
\text { (CG) } \\
{[\mathrm{n}=21]}\end{array}$ & $\mathrm{p}$ value \\
\hline Gender & $\begin{array}{l}\text { Male }=9 \\
\text { Female }=0\end{array}$ & $\begin{array}{l}\text { Male }=8 \\
\text { Female }=1\end{array}$ & $\begin{array}{l}\text { Male }=16 \\
\text { Female }=5\end{array}$ & $\begin{array}{l}1.00(\mathrm{NT} \times \mathrm{AC})^{\mathrm{a}} \\
0.28(\mathrm{NT} \times \mathrm{CG})^{\mathrm{a}} \\
0.63(\mathrm{AC} \times \mathrm{CG})^{\mathrm{a}}\end{array}$ \\
\hline Age & $59(37-64)$ & $42(39-60)$ & $45(29-65)$ & $0.10^{\mathrm{b}}$ \\
\hline Degree of severity & $\begin{array}{l}\text { Mild }=1 \\
\text { Moderate }=6 \\
\text { Severe }=2\end{array}$ & $\begin{array}{l}\text { Mild }=1 \\
\text { Moderate }=6 \\
\text { Severe }=2\end{array}$ & & $1.00^{\mathrm{a}}$ \\
\hline DID (1:) at admission & $32(4-128)$ & $16(2-64)$ & & $0.34^{c}$ \\
\hline Antifungal treatment of choice (number of patients) & - & $\begin{array}{l}\mathrm{CMX}=6 \\
\mathrm{ITZ}=2 \\
\mathrm{CMX} / \mathrm{ITZ}=1\end{array}$ & & - \\
\hline $\begin{array}{l}\text { Length of treatment } \\
\text { (median, in months) }\end{array}$ & - & $32(25-173)$ & & - \\
\hline $\begin{array}{l}\text { Time after treatment discontinuation } \\
\text { (median, in months) }\end{array}$ & - & $48(27-89)$ & & - \\
\hline
\end{tabular}

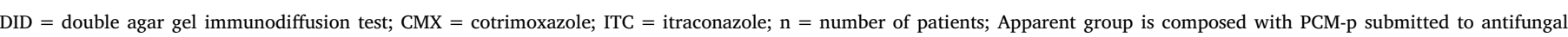
treatment who present clinical and radiological cure, negative serological tests (DID) during at least 24 months after antifungal discontinuation.

${ }^{\text {a }}$ Fisher's exact test.

${ }^{\mathrm{b}}$ Kruskal-Wallis test.

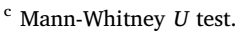

comparisons of more than two independent samples were performed using a Kruskal-Wallis test with Dunn's post-test (Zar, 2010).

\section{Results}

Although both PCM-p groups exhibited a normal counts and percentage of total PBDCs, several alterations were observed in the $\mathrm{CF}$ PCM-p, as follows: an increased counts and percentage of PB mDCs before treatment; lower counts of pDCs in the treated group; and lower percentage of $\mathrm{pDC}$ in both groups, resulting in higher PB mDC:pDC ratio in both groups than in healthy individuals (Riccardi et al., 2011) (Fig. 1).

Next, we investigated some association with these findings and serum mediators involved in chronic inflammation and fibrogenesis. Our results showed an increased serum levels of TNF- $\alpha$ in samples of CF patients, before and after treatment (Fig. 2A). No differences were observed in the levels of CCL3 (Fig. 2B) and bFGF (Fig. 2C). No levels of IL-1 $\beta$, IL-18 and IL-10 were detectable.

\section{Discussion}

Studies on DCs are usually a challenge due to the low number of these cells present in tissues and, therefore, monocytes and bone marrow-derived cells stimulated in vitro have been widely used to better mimic their role in various contexts, such as that of PCM. In contrast to those studies, herein, we evaluated some aspects of the immunobiology of fresh-isolated DCs from PCM-p, characterizing their distribution in peripheral blood.

Here, we observed high counts and percentage of $\mathrm{mDC}$ during the active disease. PB mDCs, in contrast to tissue DCs, lack dendrites and also CD83 expression, and they do not present antigens to T cells in the blood, most likely due to flow (Ziegler-Heitbrock et al., 2010). Although PB mDCs appear capable of processing circulating antigens, migrating to tissues and stimulating adaptive immunity (Thomas and Lipsky, 1994), the fine details of their regulation are not well understood. Piccoli et al. (Piccioli et al., 2007) showed that TNF- $\alpha$ was almost ineffective in inducing maturation of the mDC subset. Interestedly, PCM-p with the chronic form exhibits intense production of inflammatory cytokines, such as TNF- $\alpha$ (Calvi et al., 2003; Peraçoli et al., 2003;
Venturini et al., 2014) that was also observed in our study. During active disease, and, even though they show expansion of mDCs, the patients remain ill and do not organize an efficacious cellular immune response, suggesting that these cells could be functionally impaired. In other chronic diseases, such as chronic periodontitis (Carrion et al., 2012) and diabetes mellitus (Lo and Clare-Salzler, 2006), increased PB mDC counts have been observed. Our group has observed several immunological abnormalities in PCM-p with the chronic form after treatment. Recently, we reported increased counts of inflammatory $\mathrm{CD} 14^{+} \mathrm{CD}_{16}{ }^{+}$monocytes, high spontaneous production of TNF- $\alpha$ (Venturini et al., 2014) and enhanced NLRP3 inflammasome activation (Amorim et al., submitted) by monocytes. In addition, PCM-p with the CF also showed high counts of CD4 ${ }^{+}$T cells (Venturini et al., 2014). In the present study, we verified low counts of pDCs and high serum levels of TNF- $\alpha$ in CF-PCM patients after successful antifungal treatment. All these alterations reinforce the hypothesis that hypoxemia induced by $\mathrm{PF}$ and/or EMPH could be an important factor in these changes after treatment. As shown in Table S1 in the online version at DOI: http://dx. doi.org/10.1016/j.actatropica.2017.06.007, most of CF patients showed pulmonary sequelae since the diagnosis; thus, years of constant hypoxemia possibly are inducing alterations in the immune systems of these patients. In response to low concentrations of oxygen in tissues, cells attempt to restore homeostasis through the activation of a central regulatory system for hypoxia, called hypoxia-inducible factors (HIFs) (Wang et al., 1995). The activation of these transcription factors triggers several immune-related processes, including growth factor signaling, the release of proinflammatory cytokines and expression of co-stimulatory molecules by DCs, inducing proliferation of lymphocytes (Jantsch et al., 2008; Weidemann and Johnson, 2008).

Most of our patients showed a moderate degree of severity (Table 1), suggesting that the pDC depletion could be not related to the severe disease and highlighting the importance of conducting studies with a higher number of patients and evaluating these variables in relation to the intensity of pulmonary involvement, fibrotic scars, EMPH and the degree of hypoxemia. The decreased counts of pDCs was also observed in the histopathological examination of active skin lesions from PCM-p (Pagliari et al., 2014), where 50\% of the PCM specimens were positive for $\mathrm{CD} 123$, a marker for pDCs. Lowered pDC counts in $\mathrm{PB}$ 
A

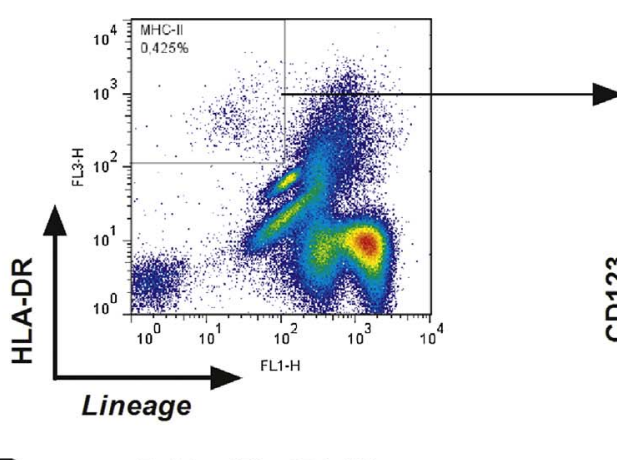

B

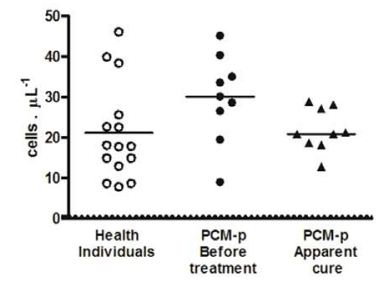

C

Peripheral Blood Myeloid DC

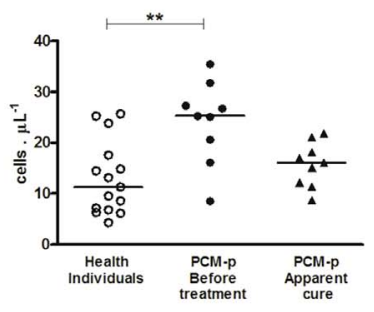

D

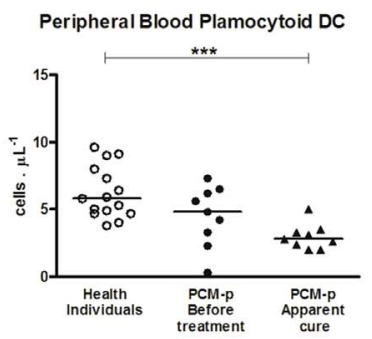

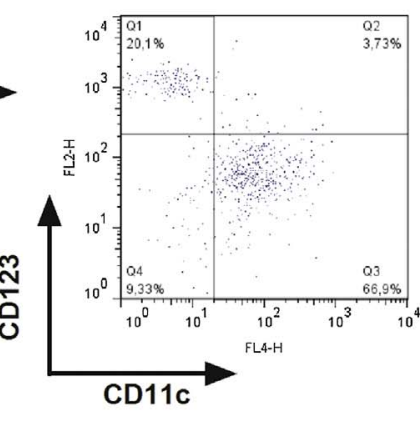

Peripheral Blood Total DC

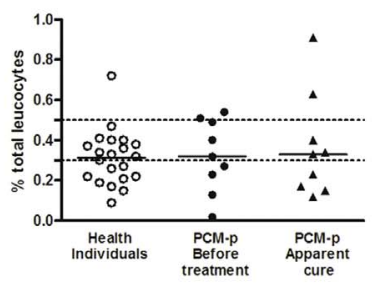

Peripheral Blood Myeloid DC

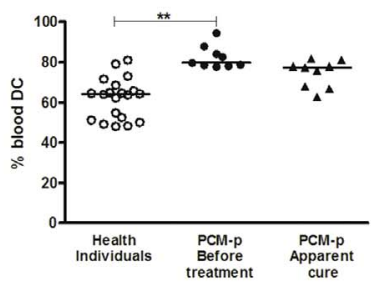

Peripheral Blood Plamocytoid DC

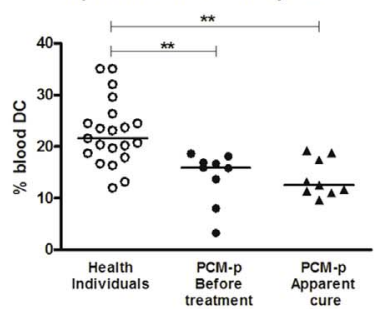

Fig. 1. Distribution of peripheral blood dendritic cells (DCs) from chronic paracoccidioidomycosis patients (PCM-p) with relation to disease activity. A) FACS gating strategy for identifying total DCs (lineage ${ }^{\text {neg }} \mathrm{HLA}-\mathrm{DR}^{+}$) and the following subsets: myeloid $(\mathrm{mDC})\left(\mathrm{CD} 11 \mathrm{c}^{+} \mathrm{CD} 123^{\text {neg }}\right)$ and plasmacytoid $\left(\mathrm{CD} 11 \mathrm{c}^{\text {neg }} \mathrm{CD} 123^{+}\right)$. B-E) Venous blood of healthy individuals, PCM-p before treatment and PCM-p after treatment (apparent cure) was tested to determine the counts and percentage of peripheral blood total DCs (B), mDCs (C), pDCs (D), and the mDC:pDC ratio (E). The results are expressed as the median, and the dashed horizontal line represents the upper and lower limits of healthy individuals, as proposed by Riccardi et al. (Riccardi et al., 2011). The apparent cure group is composed of PCMp who underwent antifungal treatment and are observed to be clinically and radiologically cured, with negative serological tests (DID), for at least two years after antifungal discontinuation. Kruskal-Wallis test with Dunn's post-test; $* p<0.05,{ }^{* *} p<0.01,{ }^{* * *} p<0.001$. CD $11 c^{\text {neg }} C D 123^{\text {neg }}$ DCs, also known as less differentiated DCs, were not include in our analyses.

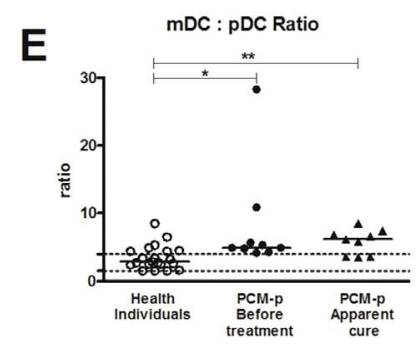

has been demonstrated in several viral infections, such as influenza (Lichtner et al., 2011) and HIV (Lichtner et al., 2008), probably due to pDC migration to lymph nodes and the spleen (Malleret et al., 2008). It is well known that pDCs produce high amounts of IFN-I during viral infections. In some fungal diseases, it was observed, for example, that this cytokine is crucial for the production of IL-17 by T cells and also for fungal clearance during experimental infection by Cryptococcus neoformans (Qin et al., 2014). In experimental paracoccidioidomycosis, the role of IFN-I in the protection is not clear; IFN- $\alpha$ was not detect in the supernatant of $P$. brasiliensis-stimulated DCs from both susceptible and resistant mouse strains (Pina et al., 2013).

Despite the recent advances in the studies on DCs subsets, further studies are necessary to fine-tune characterize the functional alterations of these cells, such as the detection of intracellular cytokines and/or surface signaling markers, and their potential to be used as a biomarker of PCM progress. Considering the atypically small number of new cases in the last years in our service and the usual long-term of antifungal treatment in PCM, studies evaluating the same patient several times is a 
A

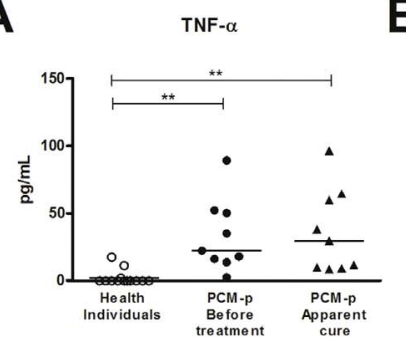

B

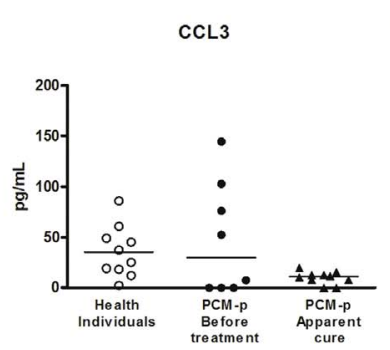

C

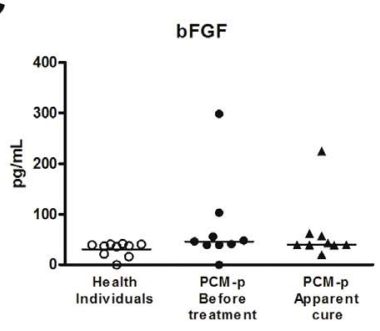

Fig. 2. Quantification of serum TNF- $\alpha$ (A), CCL3 (B) and bFGF (C). Serum blood of healthy individuals $(\mathrm{n}=10)$, PCM-p before treatment $(\mathrm{n}=9)$ and PCM$\mathrm{p}$ after treatment $(\mathrm{n}=9)$ was submitted to dosages by ELISA. Kruskal-Wallis test with Dunn's post-test; $* * p<0.01$. challenge, and we have considered this aspect to be a limitation of the present study.

\section{Conclusion}

In conclusion, we demonstrated that active PCM affects the distribution of peripheral blood DC subsets. During the active disease, PCM-p show a high count of mDCs that could be associated with continuing fungal antigen exposure and an intense pro-inflammatory response. Furthermore, after successful treatment, while the mDCs tend to regress to normal values, the counts of pDCs remains low, suggesting that antigens released from fungal carcasses (hulls) and hypoxia could influence DC differentiation and/or circulation. Therefore, we identified new evidences of persistent immunological abnormalities in PCM-p after treatment. While these patients show fungal clearance, the disability sequelae continue to interfere in the immune response.

\section{Author contributions}

JV, MSPA and RPM conceived and designed the experiments. JV, MAG, DVM and ADL performed the experiments. JV, RPM, RSC and MSPA analyzed the data. RSC, MAG, RPM and ADL contributed reagents, materials, and tools for analysis. JV and RPM wrote the paper.

\section{Funding}

This work was supported by the Fundação de Apoio a Pesquisa do Estado de São Paulo - FAPESP(\#2009/51105-1).

\section{Conflict of interest}

The authors declare that there are no conflicts of interest.

\section{Acknowledgment}

The authors are grateful to Valéria Alves da Silva for providing helpful technical support with the flow cytometry assays.

\section{References}

Almeida, S.R., Lopes, J.D., 2001. The low efficiency of dendritic cells and macrophages from mice susceptible to Paracoccidioides brasiliensis in inducing a Th1 response. Braz. J. Med. Biol. Res. 34, 529-537.

Benard, G., Hong, M.A., Del Negro, G.M., Batista, L., Shikanai-Yasuda, M.A., Duarte, A.J., 1996. Antigen-specific immunosuppression in paracoccidioidomycosis. Am. J. Trop. Med. Hyg. 54, 7-12.

Calvi, S.A., Soares, A.M.V.C., Peraçoli, M.T.S., Franco, M., Ruiz, R.L., MarcondesMachado, J., Fecchio, D., Mattos, M.C.I., Mendes, R.P., 2003. Study of bronchoalveolar lavage fluid in paracoccidioidomycosis: cytopathology and alveolar macrophage function in response to gamma interferon; comparison with blood monocytes. Microbes Infect. 5, 1373-1379.

Carrion, J., Scisci, E., Miles, B., Sabino, G.J., Zeituni, A.E., Gu, Y., Bear, A., Genco, C.A., Brown, D.L., Cutler, C.W., 2012. Microbial carriage state of peripheral blood dendritic cells (DCs) in chronic periodontitis influences DC differentiation, atherogenic potential. J. Immunol. 189, 3178-3187. http://dx.doi.org/10.4049/jimmunol. 1201053.

Cavalcante, R., de, S., Sylvestre, T.F., Levorato, A.D., de Carvalho, L.R., Mendes, R.P., 2014. Comparison between itraconazole and cotrimoxazole in the treatment of paracoccidiodomycosis. PLoS Negl. Trop. Dis. 8, e2793. http://dx.doi.org/10.1371/ journal.pntd.0002793.

Colonna, M., Trinchieri, G., Liu, Y.-J., 2004. Plasmacytoid dendritic cells in immunity. Nat. Immunol. 5, 1219-1226. http://dx.doi.org/10.1038/ni1141.

Cook, P.C., MacDonald, A.S., 2016. Dendritic cells in lung immunopathology. Semin. Immunopathol. 38, 449-460. http://dx.doi.org/10.1007/s00281-016-0571-3.

Fernandes, R.K., Bachiega, T.F., Rodrigues, D.R., Golim, M., de, A., Dias-Melicio, L.A., Balderramas, H., de, A., Kaneno, R., Soares, Â.M.V.C., 2015. Paracoccidioides brasiliensis interferes on dendritic cells maturation by inhibiting PGE2 production. PLoS One 10, e0120948. http://dx.doi.org/10.1371/journal.pone.0120948.

Ferreira, K.S., Almeida, S.R., 2006. Immunization of susceptible mice with gp43-pulsed dendritic cells induce an increase of pulmonary Paracoccidioidomycosis. Immunol. Lett. 103, 121-126. http://dx.doi.org/10.1016/j.imlet.2005.10.014.

Ferreira, K.S., Bastos, K.R., Russo, M., Almeida, S.R., 2007. Interaction between Paracoccidioides brasiliensis and pulmonary dendritic cells induces interleukin-10 production and toll-like receptor-2 expression: possible mechanisms of susceptibility. J. Infect. Dis. 196, 1108-1115. http://dx.doi.org/10.1086/521369.

Ferreira, K.S., Maranhão, A.Q., Garcia, M.C.C., Brígido, M.M., Santos, S.S., Lopes, J.D., Almeida, S.R., 2011. Dendritic cells transfected with scFv from Mab 7. B12 mimicking original antigen gp43 induces protection against experimental Paracoccidioidomycosis. PLoS One 6, e15935. http://dx.doi.org/10.1371/journal. pone.0015935.

Gimenez, M.F., Tausk, F., Gimenez, M.M., Gigli, I., 1987. Langerhans' cells in paracoccidioidomycosis. Arch. Dermatol. 123, 479-481.

Jantsch, J., Chakravortty, D., Turza, N., Prechtel, A.T., Buchholz, B., Gerlach, R.G., Volke, M., Gläsner, J., Warnecke, C., Wiesener, M.S., Eckardt, K.-U., Steinkasserer, A., Hensel, M., Willam, C., 2008. Hypoxia and hypoxia-inducible factor-1 alpha modulate lipopolysaccharide-induced dendritic cell activation and function. J. Immunol. 180, 4697-4705.

Kaminagakura, E., Bonan, P.R.F., Jorge, J., Almeida, O.P., Scully, C., 2007. Characterization of inflammatory cells in oral paracoccidioidomycosis. Oral Dis. 13, 434-439. http://dx.doi.org/10.1111/j.1601-0825.2006.01319.x.

Kapsenberg, M.L., 2003. Dendritic-cell control of pathogen-driven T-cell polarization. Nat. Rev. Immunol. 3, 984-993. http://dx.doi.org/10.1038/nri1246.

Lichtner, M., Rossi, R., Rizza, M.C., Mengoni, F., Sauzullo, I., Massetti, A.P., Luzi, G., Hosmalin, A., Mastroianni, C.M., Vullo, V., 2008. Plasmacytoid dendritic cells count in antiretroviral-treated patients is predictive of HIV load control independent of CD4+ T-cell count. Curr. HIV Res. 6, 19-27.

Lichtner, M., Mastroianni, C.M., Rossi, R., Russo, G., Belvisi, V., Marocco, R., Mascia, C., Del Borgo, C., Mengoni, F., Sauzullo, I., d'Ettorre, G., D’Agostino, C., Massetti, A.P., Vullo, V., 2011. Severe and persistent depletion of circulating plasmacytoid dendritic cells in patients with 2009 pandemic H1N1 infection. PLoS One 6, e19872. http://dx. doi.org/10.1371/journal.pone.0019872.

Lo, J., Clare-Salzler, M.J., 2006. Dendritic cell subsets and type I diabetes: focus upon DCbased therapy. Autoimmun. Rev. 5, 419-423. http://dx.doi.org/10.1016/j.autrev. 2005.12.001.

MacDonald, K.P.A., Munster, D.J., Clark, G.J., Dzionek, A., Schmitz, J., Hart, D.N.J., 2002. Characterization of human blood dendritic cell subsets. Blood 100, 4512-4520. http://dx.doi.org/10.1182/blood-2001-11-0097.

Magalhães, A., Ferreira, K.S., Almeida, S.R., Nosanchuk, J.D., Travassos, L.R., Taborda, C.P., 2012. Prophylactic and therapeutic vaccination using dendritic cells primed with peptide 10 derived from the 43-kilodalton glycoprotein of Paracoccidioides brasiliensis. Clin. Vaccine Immunol. 19, 23-29. http://dx.doi.org/10.1128/CVI. 05414-11.

Malleret, B., Manéglier, B., Karlsson, I., Lebon, P., Nascimbeni, M., Perié, L., Brochard, P., Delache, B., Calvo, J., Andrieu, T., Spreux-Varoquaux, O., Hosmalin, A., Le Grand, R., Vaslin, B., 2008. Primary infection with simian immunodeficiency virus: plasmacytoid dendritic cell homing to lymph nodes, type I interferon, and immune suppression. Blood 112, 4598-4608. http://dx.doi.org/10.1182/blood-2008-06-162651.

Mendes, R.P., 1994. The gamut of clinical manifestations. In: Franco, M., Lacaz, C.S., Restrepo-Moreno, A., Del Negro, G. (Eds.), Paracoccidioidomycosis. CRC Press, Boca Raton, pp. 233-258.

Osugi, Y., Vuckovic, S., Hart, D.N.J., 2002. Myeloid blood CD11c + dendritic cells and monocyte-derived dendritic cells differ in their ability to stimulate $\mathrm{T}$ lymphocytes. Blood 100, 2858-2866. http://dx.doi.org/10.1182/blood.V100.8.2858.

Pagliari, C., Sotto, M.N., 2003. Dendritic cells and pattern of cytokines in paracoccidioidomycosis skin lesions. Am. J. Dermatopathol. 25, 107-112.

Pagliari, C., Kanashiro-Galo, L., de L. Silva, A.A., Barboza, T.C., Criado, P.R., Duarte, M.I.S., Brito, A.C., de Xavier, M.B., Unger, D., Maria Moraes Oliveira, C., Quaresma, J.A.S., Sotto, M.N., 2014. Plasmacytoid dendritic cells in cutaneous lesions of patients with chromoblastomycosis, lacaziosis, and paracoccidioidomycosis: a comparative analysis. Med. Mycol. 52, 397-402. http://dx.doi.org/10.1093/mmy/myt026.

Peraçoli, M.T.S., Kurokawa, C.S., Calvi, S.A., Mendes, R.P., Pereira, P.C.M., Marques, S.A., 
Soares, A.M.V.C., 2003. Production of pro- and anti-inflammatory cytokines by monocytes from patients with paracoccidioidomycosis. Microbes Infect. 5, 413-418.

Piccioli, D., Tavarini, S., Borgogni, E., Steri, V., Nuti, S., Sammicheli, C., Bardelli, M., Montagna, D., Locatelli, F., Wack, A., 2007. Functional specialization of human circulating CD16 and CD1c myeloid dendritic-cell subsets. Blood 109, 5371-5379. http://dx.doi.org/10.1182/blood-2006-08-038422.

Pina, A., de Araujo, E.F., Felonato, M., Loures, F.V., Feriotti, C., Bernardino, S., Barbuto, J.A.M., Calich, V.L.G., 2013. Myeloid dendritic cells (DCs) of mice susceptible to paracoccidioidomycosis suppress $\mathrm{T}$ cell responses whereas myeloid and plasmacytoid DCs from resistant mice induce effector and regulatory T cells. Infect. Immun. 81, 1064-1077. http://dx.doi.org/10.1128/IAI.00736-12.

Qin, H.-J., Feng, Q.-M., Fang, Y., Shen, L., 2014. Type-I interferon secretion in the acute phase promotes Cryptococcus neoformans infection-induced Th17 cell polarization in vitro. Exp. Ther. Med. 7, 869-872. http://dx.doi.org/10.3892/etm.2014.1517.

Riccardi, F., Della Porta, M.G., Rovati, B., Casazza, A., Radolovich, D., De Amici, M., Danova, M., Langer, M., 2011. Flow cytometric analysis of peripheral blood dendritic cells in patients with severe sepsis. Cytometry B Clin. Cytom. 80, 14-21. http://dx. doi.org/10.1002/cyto.b.20540.

Sato, P.K., Oshiro, T.M., Diogo, C.L., Passos, E.C., Shikanai-Yasuda, M.A., 2011. Characterization of monocyte-derived dendritic cells from patients with active and treated paracoccidioidomycosis. Scand. J. Immunol. 74, 609-618. http://dx.doi.org/ 10.1111/j.1365-3083.2011.02614.x.

Shikanai-Yasuda, M.A., Telles Filho F. de, Q., Mendes, R.P., Colombo, A.L., Moretti, M.L., 2006. Guidelines in paracoccidioidomycosis. Rev. Soc. Bras. Med. Trop. 39, 297-310.

Silvana dos Santos, S., Ferreira, K.S., Almeida, S.R., 2011. Paracoccidioides brasilinsisinduced migration of dendritic cells and subsequent T-cell activation in the lungdraining lymph nodes. PLoS One 6, e19690. http://dx.doi.org/10.1371/journal. pone. 0019690
Tavares, A.H., Derengowski, L.S., Ferreira, K.S., Silva, S.S., Macedo, C., Bocca, A.L., Passos, G.A., Almeida, S.R., Silva-Pereira, I., 2012. Murine dendritic cells transcriptional modulation upon Paracoccidioides brasiliensis infection. PLoS Negl. Trop. Dis. 6, e1459. http://dx.doi.org/10.1371/journal.pntd.0001459.

Teixeira, M.M., Theodoro, R.C., de Carvalho, M.J.A., Fernandes, L., Paes, H.C., Hahn, R.C., Mendoza, L., Bagagli, E., San-Blas, G., Felipe, M.S.S., 2009. Phylogenetic analysis reveals a high level of speciation in the Paracoccidioides genus. Mol. Phylogenet. Evol. 52, 273-283. http://dx.doi.org/10.1016/j.ympev.2009.04.005.

Thomas, R., Lipsky, P.E., 1994. Human peripheral blood dendritic cell subsets: isolation and characterization of precursor and mature antigen-presenting cells. J. Immunol. 153, 4016-4028.

Venturini, J., Cavalcante, R., de Assis Golim, M., Marchetti, C., de Azevedo, P., Amorim, B., de Arruda, M., Mendes, R., 2014. Phenotypic and functional evaluations of peripheral blood monocytes from chronic-form paracoccidioidomycosis patients before and after treatment. BMC Infect. Dis. 14 (552). http://dx.doi.org/10.1186/s12879014-0552-X.

Wang, G.L., Jiang, B.H., Rue, E.A., Semenza, G.L., 1995. Hypoxia-inducible factor 1 is a basic-helix-loop-helix-PAS heterodimer regulated by cellular $\mathrm{O} 2$ tension. Proc. Natl. Acad. Sci. U. S. A. 92, 5510-5514.

Weidemann, A., Johnson, R.S., 2008. Biology of HIF-1alpha. Cell Death Differ. 15, 621-627. http://dx.doi.org/10.1038/cdd.2008.12.

Zar, J.H., 2010. Biostatistical Analysis, 5th ed. Prentice-Hall/Pearson, Upper Saddle River, N. J.

Ziegler-Heitbrock, L., Ancuta, P., Crowe, S., Dalod, M., Grau, V., Hart, D.N., Leenen, P.J.M., Liu, Y.-J., MacPherson, G., Randolph, G.J., Scherberich, J., Schmitz, J., Shortman, K., Sozzani, S., Strobl, H., Zembala, M., Austyn, J.M., Lutz, M.B., 2010. Nomenclature of monocytes and dendritic cells in blood. Blood 116, e74-80. http:// dx.doi.org/10.1182/blood-2010-02-258558. 